Marquette University

e-Publications@Marquette

English Faculty Research and Publications

English, Department of

$1-1-2001$

\title{
Louisa May Alcott, William T. Adams, and the Rise of Gender-Specific Series Books
}

Sarah Wadsworth

Marquette University, sarah.wadsworth@marquette.edu

Accepted version. The Lion and the Unicorn: A Critical Journal of Children's Literature, Vol. 25, No. 1 (January 2001): 17-46. DOI. (C) 2001 The Johns Hopkins University Press.

This article first appeared in The Lion and the Unicorn, Volume 25, Issue 1, January, 2001, pages 17-46. Reprinted with permission by The Johns Hopkins University Press.

Sarah Wadsworth was affiliated with the University of Minnesota at the time of publication. 


\section{Louisa May Alcott, William T. Adams, and the Rise of Gender-Specific Series Books}

By Sarah A. Wadsworth

Few gentlemen, who have occasion to visit news-offices, can have failed to notice the periodical literature for boys, which has been growing up during the last few years. The increase in the number of these papers and magazines, and the appearance, from time to time, of new ones, which, to judge by the pictures, are always worse than the old, seem to indicate that they find a wide market.

(William G. Sumner, 1878)

Girls, like boys, in recent years have been remarkably favoured in the matter of their reading. They cannot complain, with any justice, that they are ignored in the piles of juvenile literature laid annually upon the booksellers' shelves. Boys boast of a literature of their 'very own,' as they would call it. So do girls. ... [T]hat so-called 'girls' books' continue to be published in shoals annually is sufficient proof that there is a market for them.

(Edward G. Salmon, 1886)

Writing in 1878 and 1886 respectively, William G. Sumner and Edward G. Salmon point to a newly emergent trend in British and American juvenile literature: the development of distinct categories of literature written expressly for boys or expressly for girls. To the twentieth-century reader, raised on Nancy Drew or the Hardy Boys, Trixie Belden or Danny Dunn, the Baby-Sitters' Club or Encyclopedia Brown, such a division may seem a natural and obvious one. As Salmon's observation suggests, however, the shift from a more or less homogenous body of literature for "boys and girls" to a body of juvenile fiction bifurcated by gender was considered an innovation in the latter half of the nineteenth century. ${ }^{1}$ In the United States, the transformation began gradually in the 1830s, 1840s, and 1850s with popular authors such as Jacob Abbott, William T. Adams (“Oliver Optic”), and Rebecca Sophia Clarke (“Sophie May”), gaining momentum in the 1860s, 1870s, and 1880s with the contributions of Louisa May Alcott, Horatio Alger, and Mark Twain, and accelerating rapidly toward the close of the nineteenth century as a result of publishers' unflagging efforts in the fields of gender-specific periodicals, dime novels, and, especially, series books.

While many critics have noted that "adolescent or preadolescent boys and girls historically were not encouraged to share reading material" (Vallone 122), few distinguish between books written for either gender but appropriated primarily by one or the other (for example, Robinson Crusoe) and books written with a single-sex target audience in mind. An exception is Gillian Avery, who observes, "[f]rom the mid-century onwards, as juvenile publishing became an industry, what had been unisex developed into two sharply differentiated categories. Writing for boys, and writing for girls, became professions in themselves" 
(190). As Avery suggests, the segmentation of the juvenile fiction market closely parallels the development of children's literature as a specialized branch of publishing. ${ }^{2}$

In this essay, I illustrate the relationship between the segmentation of the juvenile fiction market by gender and the commercialization of children's publishing through an examination of the careers of William T. Adams and Louisa May Alcott. Perhaps more than any other writers in nineteenth-century America, these two authors exemplify how "[w]riting for boys, and writing for girls, became professions in themselves." As early practitioners of gendered juvenile series, Alcott and Adams together illustrate the separation of boys' and girls' reading in the United States in the mid- to late-nineteenth century. A side-by-side study of these two authors and their juvenile series shows that Alcott was both responding to and writing against Oliver Optic's books. At the same time, Alcott's books for girls reveal that she simultaneously resisted and revised traditional models of femininity while mediating her readers' desire for conventional female plots. As a result, Alcott brought about an important development in the history of juvenile literature: in shaping a new kind of fiction aimed specifically at adolescent girls, she ushered in realistic female characters and plots that were as distinct from previous models of femininity and womanhood in fiction, as from the characters and plots of the boys' books against which they were inevitably defined. Ultimately, however, the impact of Adams and Alcott extended beyond the books they wrote to the audiences who read them. For, in recognizing the changing roles of boys and girls in American society and their still-tentative presence in the maturing literary marketplace, they (and their publishers) effectively brought these segments of the juvenile fiction market into existence. Just as Adams helped to define not only boys' series but also the audience for boys' books, so Alcott, as the most important contemporary American author to write books specifically for girls, was instrumental in defining, shaping, reinforcing, and revising the qualities, interests, and aspirations of the girls who comprised that market. ${ }^{3}$

In the second volume of Little Women, Louisa May Alcott describes Jo March's efforts to produce a type of story that would be both saleable and respectable. After her friend (and future husband) Professor Bhaer persuades her that sensational stories are morally corrupting to young readers, Jo abandons this lucrative genre and attempts a tale in the bland, unobjectionable style of Mary Sherwood, Maria Edgeworth, and Hannah More. ${ }^{4}$ The result, Alcott writes, "might have been more properly called an essay or a sermon, so intensely moral was it" (366). After failing to find a purchaser for "this didactic gem" (366), Jo turns her hand to juvenile fiction:

Then she tried a child's story, which she could easily have disposed of if she had not been mercenary enough to demand filthy lucre for it. The only person who offered enough to make it worth while to try juvenile literature was a worthy gentleman who felt it his mission to convert all the world to his particular belief. But much as she liked to write for children, Jo could not consent to depict all her naughty boys as being eaten by bears or

Wadsworth 2 
tossed by mad bulls, because they did not go to a particular Sabbath-school, nor all the good infants, who did go, as rewarded by every kind of bliss, from gilded ginger-bread to escorts of angels, when they departed this life with psalms or sermons on their lisping tongues. So nothing came of these trials; and Jo corked up her inkstand . . . . (366)

Unlike her semi-autobiographical protagonist, Alcott refused to cork up her own inkstand but instead went on to write numerous stories for children, beginning with fairy tales in the mid- $1850 \mathrm{~s}^{5}$ and continuing largely in the fantasy mode promoted by Hawthorne (through his A Wonder-Book [1851] and Tanglewood Tales [1853]) up until about $1868 .{ }^{6}$ Finally, in the spring of that year, she hit upon a combination of style and subject matter that succeeded in earning her the stacks of "filthy lucre" she dreamed of, in addition to literary fame and respectability as the author of Little Women.

Louisa May Alcott did not want to write girls' books, however. In fact, she was rather strongly opposed to the suggestion, offered by Thomas Niles of Roberts Brothers, that she write a novel for girls. In retrospect, her distaste for the project (which she recorded in a journal entry of September 1867) is amusing:

Niles, partner of Roberts, asked me to write a girls book. Said I'd try. Fuller asked me to be the Editor of "Merry's Museum." Said I'd try. Began at once on both new jobs, but didn't like either. (Journals 158)

As it happened, the task of editing Merry's Museum ${ }^{7}$ proved to be quite a drain on Alcott's time and energy, and her progress on the "girls book" was no doubt hindered as much by the demands of reading manuscripts and writing her monthly story and editorial as by her obvious resistance to the project Niles proposed.

While Alcott continued to favor fairy tales, writing for Merry's Museum an eight-part serial entitled Will's Wonder Book as well as several other fantasy stories, ${ }^{8}$ Niles renewed his interest in her "girls book." In May 1868, his prompting elicited another tepid response from Alcott:

Father saw Mr. Niles about a fairy book. Mr. N. wants a girls' story, and I begin "Little Women.” Marmee, Anna, and May all approve my plan. So I plod away, though I don't enjoy this sort of thing. Never liked girls or knew many, except my sisters; but our queer plays and experiences may prove interesting, though I doubt it. (Journals 165-66)

The following month, she again voiced her lack of enthusiasm, noting in her journal that she had Sent twelve chapters of "L. W." to Mr. N. He thought it $d u l l$; so do I. But work away and mean to try the experiment; for lively, simple books are very much needed for girls, and perhaps I can supply the need. (Journals 166)

The source of this mingled diffidence and indifference seems to arise in part from Alcott's penchant for fairy tales and inexperience with the newfangled genre of "girls' books" and in part from her preference for 
boys over girls, both in literature and in life. To Alfred Whitman (one of the models for the fictional Laurie), Alcott had confided:

There was always something very brave \& beautiful to me in the sight of a boy when he first "wakes up" \& seeing the worth of life takes it up with a stout heart \& resolves to carry it nobly to the end through all disappointments \& seeming defeats. I was born with a boys nature \& always had more sympathy for $\&$ interest in them than in girls, \& have fought my fight for nearly fifteen [years] with a boys spirit under my "bib \& tucker" \& a boys wrath when I got "floored" .... (Letters 51-52)

As her friend and biographer Ednah Cheney attested, "Miss Alcott's fancy had always been for depicting the life of boys rather than girls" (155), ${ }^{9}$ and in Little Women, Alcott even has Jo, her alter ego, declare that she likes "boys' games and work and manners" and cannot get over her "disappointment in not being a boy" (5). ${ }^{10}$ Given this predilection, then, it is likely that had Niles not urged her to write a girls' book, Alcott might never have attempted the novel that debuted the following year as Little Women: Meg, Jo, Beth, and Amy. The Story of Their Lives. A Girls' Book. ${ }^{11}$

Thomas Niles's persistence in the face of Alcott's continuing reluctance is perhaps surprising until we consider both the unprecedented success then being enjoyed by authors of "realistic" juvenile fiction and the talent of this up-and-coming editor for assessing the literary market of the day. ${ }^{12}$ Alcott's biography reveals that a powerful incentive to Niles (and, by extension, to Alcott) was provided by the example of "Oliver Optic" in the arena of boys' books. Niles's obituary in Publishers Weekly (9 June 1894) reported that " $[t]$ he success of Oliver Optic's books suggested to Mr. Niles the thought of similar books for girls, and having been much pleased by 'Hospital Sketches,' by Louisa M. Alcott, published in 1867 by Ticknor \& Fields, he sent for Miss Alcott and engaged her for this work" (“T. Niles" 859-60). More recently, Gene Gleason related that Niles asked Alcott to “'do something like Oliver Optic,' but for girls” (648). Madeleine Stern reconstructs the scenario in her biography of Alcott as follows:

From his office at number 143 Washington Street he [Niles] had seen vast quantities of books by "Oliver Optic" leaving the rooms of Lee and Shepard at number 149. There must be a similar market for a full-length novel that would be as popular among girls as "Oliver Optic's" narratives were among boys. $(168)^{13}$

Who was this paragon of juvenile authorship who reportedly inspired both Thomas Niles and Louisa May Alcott to experiment with realistic fiction aimed specifically at adolescent girls? With approximately 126 books to his credit, "Oliver Optic" was the enormously prolific Reverend William Taylor Adams (1822-1897), whose most popular books sold at a rate of more than 100,000 a year (Gay 16). The indefatigable Adams also wrote approximately 1,000 short stories, used at least eight different 
pseudonyms, and was editor, at various times, of Student and Schoolmate, Our Little Ones, and Oliver Optic's Magazine (Our Boys and Girls) (Gleason 647-48). By the time of his death, an estimated two million copies of his books had been sold, making the former principal and Sunday-school teacher one of the best-paid writers of his time as well as (according to at least one source) the most widely read (Jones xvi). ${ }^{14}$ Given that Niles evidently hoped that Alcott might provide a female counterpart to Adams's fabulously popular boys' books, a glimpse into the career of the illustrious "Oliver Optic" provides some insight into the role of the Little Women Series in the nineteenth-century literary marketplace.

Just as Niles prompted Alcott with the suggestion that she write a book for girls, so Adams's publisher provided the initial impetus for the young minister to write a book for boys. ${ }^{15}$ Adams's lack of confidence in the undertaking mirrors Alcott's. According to Raymond L. Kilgour:

... when he was asked to try a book for boys he declined, saying he couldn't do such a thing. Being finally persuaded, he wrote The Boat Club (1855), which was so popular that he could no longer resist, and followed it with five more. (Lee and Shepard 30)

Although originally published by Brown, Bazin and Co., The Boat Club: or The Bunkers of Rippleton. A Tale for Boys (dated 1854), a story about two rival groups of boys and their boating adventures on a New England lake, was picked up by Phillips, Sampson in 1855 and later republished by William Lee, who spurred Adams on to produce sequel after sequel. Lee, as a partner in the newly established firm of Lee $\&$ Shepard, capitalized on the popularity of the six-volume Oliver Optic's Library for Young People (which he helped to create) and managed to keep Adams in his stable of authors for the next forty years.

By the mid-1860s, William Lee and Charles Shepard, whose firm was to become the largest publisher of children's books in the United States from the 1860 s to the late $1880 \mathrm{~s},{ }^{16}$ had arrived at some important realizations concerning the juvenile fiction market. First, they had discovered during the Civil War that children's books sold well even in difficult economic times. Second, they found that long-term sales were largely responsible for the success of their juvenile productions: many of their children's books proved to be steady-sellers for several generations (perhaps in part because parents and older siblings influence the reading tastes of children), and so, in accordance with the laws of supply and demand, these evergreens appeared season after season, often updated with new bindings and enhanced, from time to time, with new illustrations.

Lee and Shepard also displayed a rare gift for marketing. In 1884, fellow publisher J. C. Derby marveled that "[t]hey seem to know intuitively the salable qualities of a book" (519). As Kilgour explains, their strategy "was to get a wide variety of books, for children of all ages, and to advertise them to the limit" (35). ${ }^{17}$ In addition to aggressive advertising, Lee and Shepard pioneered the marketing tactic of issuing as sets books that were initially sold separately. The practice of cobbling together half a dozen loosely related 
books by a single author was supplemented in time by series consisting of various authors ${ }^{18}$ as well as single-author series that were more unified in terms of character and narrative (for example, Oliver Optic's Lake Shore Series, Young America Abroad Series, and others). Sometimes the firm divided an author's juvenile books by gender and then marketed them to single-sex audiences. More often, however, individual authors became strongly associated with either the boys' market or the girls' market: while such authors as "Sophie May," Amanda M. Douglas, and Virginia F. Townsend wrote for girls, authors such as Elijah Kellogg, J. T. Trowbridge, and James De Mille joined Oliver Optic in writing for boys. This practice culminated in author series such as Kellogg's Elm Island Series and De Mille's Young Dodge Club Series and in two gender-specific publishers' series launched in the early 1870s: the American Boys' Library and the complementary American Girls' Library.

Not only did Lee \& Shepard have more authors writing for boys than for girls, however, but their series for boys achieved a kind of a commercial success that none of their girls' series managed to approach. In general, their boys' series had stronger series identities and ran to many more volumes than their series for girls. Fueled by their success in the boys' market and hoping to correct the imbalance, Lee \& Shepard decided to enlist their most popular boys' author in a bold attempt to jumpstart their lagging trade in girls' books. Oliver Optic's Library for Young People and the subsequent Riverdale Story Books, which William Lee had acquired from Phillips, Sampson, had been so successful with the attractive new bindings and illustrations by Hammatt Billings that Lee \& Shepard provided "that Adams was summoned to the publishers' office and asked to prepare a new series for girls—which might also be read by boys!" (Kilgour, Lee \& Shepard 35). ${ }^{19}$ Adams agreed to give it a try. The preface to Little by Little (1860), the last of the Boat Club Series, anticipates the shift of audience (and illustrates differences in the literary tastes that boys and girls were presumed to possess), as Adams writes:

Paul Duncan, the hero of this volume, is a nautical young gentleman, and most of the events of the story occur upon the water; but the author hopes his young lady friends will not make faces at him on this account. The boys insisted upon having a sea story, and being the "lords of creation," of course they must be indulged; but the writer most solemnly promises to remember the girls next time. (6)

The promised volume for girls was Rich and Humble; or, The Mission of Bertha Grant (1864), the first volume of the Woodville Stories, in which Adams confirms:

Agreeably to the promise made in the preface of "Little by Little," the author presents the following story to his young lady friends, though he confidently expects it will prove as acceptable to the embryo "lords of creation" as to those for whom it was more especially written. (5)

Wadsworth 6 
What is perhaps most interesting about Rich and Humble is the explicit claim it makes to targeting a female audience - a claim that is borne out in the novel itself, which revolves around a virtuous girl's journey from luxury to penury and back. Adams had been writing boys' books for more than a decade by the time this novel was published, however, and he was clearly reluctant to abandon his primary audience. As earlier entries in the field of children's literature suggested-and The Boat Club Series undeniably proved—books for boys constituted a viable sector of the juvenile fiction market, while girls' books were as yet something of an unknown quantity. Despite its claims to addressing a female readership, Rich and Humble carries the subtitle "A Story for Young People," and the series is designated "A Library for Boys and Girls." Moreover, in his preface to the volume, Adams addresses male and female readers in turn, directing the attention of the two groups of readers to different aspects of the text:

The girls will find that Bertha Grant is not only a very good girl, but that her life is animated by a lofty purpose, which all may have, though they fail to achieve the visible triumphs that rewarded the exertions of the heroine of "Rich and Humble."

The boys will find that Richard Grant was not always a good boy because his life was not animated by a lofty purpose; but the author hopes, in another volume, to present him in a higher moral aspect, and more worthy the imitation of those who, like him, have wandered from the true path. (5)

Aware that his readers would be most interested in characters of their own sex, Adams was careful to include in the novel enough male characters (including a ragamuffin who bears a remarkable resemblance to Huckleberry Finn) and enough sport and rowdiness to satisfy most of Oliver Optic's customary audience of boys. (In fact, Lee \& Shepard later reissued the novel as volume \#33 of their American Boys' Series.) Rich and Humble was not an immediate success; still, the long-term sales of this domestic novel eventually outpaced many of Adams's boys' books (Kilgour 39-40), providing persuasive corroboration that a ready market for girls' series books awaited those prepared to meet its demands. ${ }^{20}$ Nevertheless, Adams seems not to have repeated the experiment of focusing on a primarily female audience. ${ }^{21}$

Of course, just as fiction for boys was preceded by practical advice books for boys, ${ }^{22}$ girls, too, had their own handbooks, conduct books, and lesson books_-volumes such as Lydia Maria Child's The Little Girl's Own Book (1831), The American Girl's Book (1831), edited by Eliza Leslie, Mrs. A. J. Graves's The Young Lady's Book of Good Examples (1848), and Lydia Sigourney's Letters to Young Ladies (1833) and The Girls' Reading-Book (1838). There were even the "courtesy novels" of the late eighteenth and early nineteenth centuries. Linda C. Hunt explains:

As the novel developed, the courtesy book could not compete with the novels from the circulating library which were so much more entertaining, and so the courtesy book writers 
attempted to liven their teachings by fictional devices borrowed from the novel. At the same time some of the novelists attempted to justify and dignify the new genre by including the moral and utilitarian material of the courtesy books. (9)

In spite of these early beginnings, however, realistic fiction written specifically for the amusement of young girls was still uncommon a full decade after the appearance of Oliver Optic's books for boys. While Lee \& Shepard exhibited customary foresight in staking out a corner of the girls' market, most publishers did not yet consider it necessary or sufficiently profitable to publish books for this particular subset of readers.

One reason for the recognition of boys as a separate audience well before girls was that the boys' market was seen as including girls, while the girls' market apparently excluded boys. In fact, it was a common perception that boys required a separate body of literature. Girls, however, could enjoy both domestic tales and adventure stories directed at a male audience. ${ }^{23}$ The popular British children's author Charlotte M. Yonge (who had been producing novels for teenage girls in England since the mid-1850s and whom Alcott read as a young woman [Crisler 35]) explained her decision to include a category of "boys' books" without a complementary listing of "girls' books" in her compendium of What Books to Give and What to Lend (1887):

The mild tales that girls will read simply to pass away the time are ineffective with [boys] . . . the works therein [this catalogue] are not merely suited to lads, for though girls will often greatly prefer a book about the other sex, boys almost universally disdain books about girls. $(29-30)^{24}$

Yonge's view is corroborated by the American Robert M. Lovett, who, in his 1926 article “A Boy's Reading Fifty Years Ago," confessed that reading girls' books was a habit he "fell into ... in a period of starvation" and one of which he had been "ashamed" (335). ${ }^{25}$ Alcott was well aware of this literary fact, for in Little Women she has Jo read boys' books, and even delicate Beth finds occasion to feel "glad that she had read one of the boys' books in which Jo delighted" (152). ${ }^{26}$ Even well into the twentieth century, a commentator on "Trends in Children's Books" announced that “. . . librarians report an appetite for so-called boys' books by girls, but no corresponding eagerness by boys" (Evans 337). ${ }^{27}$ Given these attitudes toward boys' and girls' reading, it is not difficult to see why entertaining novels conceived specifically for boys emerged earlier than comparable books for girls.

The belated discovery of girls as a separate audience was also influenced by a persistent misapprehension of what girls wanted to (or should) read. Although Oliver Optic was not without critics (especially late in his career), his tales of outdoor adventure for boys were widely praised. Long after the fading of the notion that boys must be spoon-fed didactic and moral tales of the type Alcott satirizes in Little Women, stories for girls continued to consist largely of sugar-coated lessons in morality and femininity. 
Many seemed to agree with Charlotte Yonge's assessment that "[i]f the boy is not to betake himself to 'Jack Sheppard' literature, he must be beguiled by wholesome adventure," while "If the girl is not to study the 'penny dreadful,' her notions must be refined by the tale of high romance or pure pathos" $(6) .{ }^{28}$ One result of this double standard was that authors, publishers, and parents continued to encourage girls to keep a carefully restricted diet consisting largely of pious narratives of the Elsie Dinsmore school, while permitting boys to feast their fancies on fast-paced stories of travel and adventure. Another result, however, was that girls eagerly appropriated their brothers' books since, as Salmon averred, "they [could] get in boys' books what they [could not] get in the majority of their own-stirring plot and lively movement" (524). ${ }^{29}$

The discrepancy between boys' and girls' literary fare reflects the divergent roles of boys and girls in nineteenth-century society. As Anne Scott MacLeod points out, "Realistic children's literature nearly always bends toward socializing the young, imparting values, and distinguishing desirable behavior from the deplorable" (American Childhood 54). Boys' and girls' novels of the nineteenth century accomplished these tasks through plot as well as characterization: "Where the boys' books increasingly revolved around a young man's encounter with the outside world—in the army, in the West, in the city-and around active, extroverted adventure, girls' novels focused on character and relationships, as, of course, girls' lives did as they approached womanhood" (MacLeod, American Childhood 14). ${ }^{30}$ Salmon's 1886 article "What Girls Read" explicitly prescribed the manner in which juvenile literature should prepare British children for their future roles as grown men and women:

Boys' literature of a sound kind ought to build up men. Girls' literature ought to help to build up women. If in choosing the books that boys shall read it is necessary to remember that we are choosing mental food for the future chiefs of a great race, it is equally important not to forget in choosing books for girls that we are choosing mental food for the future wives and mothers of that race. (526)

Literature for American children had its own cultural work to perform in preparing boys and girls for adulthood, and for girls this meant teaching them that a woman's most valuable contribution was in using her feminine influence for good and virtuous ends within the context of the domestic sphere. ${ }^{31}$

Alcott's entry into the largely untried arena of realistic fiction for girls marked an important advance in the social function of girls' reading. ${ }^{32}$ Responding positively to the gradual widening of the female sphere and increasing opportunities for women, Little Women and its sequels acknowledge girls as more than future wives and mothers, advocate education and career opportunities for women, and celebrate the individuality of spirited, intelligent, independent young women. In Little Women, which was hailed as "[a] capital story for girls" ("New Publications" 857), ${ }^{33}$ two of the three sisters who reach adulthood pursue careers other than (or in addition to) that of homemaker: Jo as a writer and Amy as an artist. In subsequent 
volumes of the Little Women series, Alcott's concern with female education, training, and professionalization is even more conspicuous. ${ }^{34}$ In An Old-Fashioned Girl, for example, Polly supports herself as a young woman in Boston teaching music to children. In Eight Cousins, Alcott shows the effects of a progressive education on a young girl - an education that includes arithmetic and physiology in addition to culinary and needle arts. She pursues this theme further in Rose in Bloom, in which the heroine defers thoughts of courtship and marriage, resolving, "I won't have anything to do with love till I prove that I am something beside a house-keeper and baby-tender!” (10). Finally, in Jo's Boys, Alcott paints Laurence College as a coeducational institution, where the girls are encouraged to be career-minded, like Nan, a student of medicine. Even when working within the traditional boundaries of female roles, Alcott used her children's stories as a platform from which to lobby for improvements in girls' education. With respect to Eight Cousins, for example, she argued:

Young girls in America do not get a good education in various respects, even though much is taught to them. They know nothing of health care, or of housekeeping, and are presented into society too early. My story is intended to encourage a better plan of child-rearing, and my heroine shows that such a plan is feasible. (Letters 194) ${ }^{35}$

As a girl, Louisa May Alcott may have been "the opposite of everything her family—and nineteenth-century New England—required a young woman to be" (Girlhood Diary 1). Nevertheless, as the spectacular popularity of the Little Women Series attests, her female protagonists represented precisely what the next generation of young women desired their heroines in fiction to be.

Ironically, Oliver Optic, the quintessential boys' author of the mid-nineteenth century, may have inspired Alcott not only with the marketplace success of his books for boys but also, indirectly, with his creation of determined female characters who offered readers more than a lesson in docility and daintiness, matrimony and motherhood. Rich and Humble, in which he specifically sought to address a female audience, was actually preceded, in 1858, by Poor and Proud; Or, The Fortunes of Katy Redburn, an Algeresque story about an eleven-year-old girl who raises herself and her mother, an invalid, from poverty through her own industry and discovers in the end that she is an heiress. ${ }^{36}$ In A Hunger for Home: Louisa May Alcott and Little Women, Sarah Elbert writes:

In addition to boys' "Great Western Series," "Lake Shore Series," and "Yacht Club Series," he [Adams] had also produced a promising girls' story about "Katy Redmond" [sic] ${ }^{37}$ His heroine was a self-reliant twelve-year-old whose exploits signalled a change in girls' fiction that struck a responsive note in Louisa. (142)

Although Poor and Proud is hardly a revolutionary story, its protagonist does have a kind of perseverance and independence that was still rare among female characters in juvenile literature. ${ }^{38}$ (In his preface to Poor 
and Proud, Adams characterizes Katy as "a smart girl" [v].) Even as the spirited Katy is a substantial improvement over the earlier stock of nineteenth-century juvenile heroines, however, Alcott far surpassed Adams in her creation of the March sisters, and especially in her delineation of Jo. Jo March—boyish, impetuous, high-spirited, and quick-tempered—represents a new kind of heroine in juvenile fiction, one who would resonate strongly with generations of female readers to come. ${ }^{39}$

Although Alcott attributed the success of Little Women to its realistic portrayal of girls' lives, ${ }^{40} \mathrm{Jo}$, the central character, has typically been regarded as an exceptional, rather than a typical, example of nineteenth-century girlhood. Certainly, Alcott's portrayal of Jo flouts the characteristics ascribed by convention to nineteenth-century heroines. Alcott writes, "Round shoulders had Jo, big hands and feet, a fly-away look to her clothes, and the uncomfortable appearance of a girl who was rapidly shooting up into a woman, and didn't like it" (Little Women 6). As MacLeod has recently argued, however, tomboyism, followed by its forced abandonment in the mid- to late teens, was far more widespread among American girls of the nineteenth century than convention has led us to expect. Drawing on diaries, letters, and memoirs, as well as fictional accounts, MacLeod suggests that girls of the later nineteenth century often enjoyed the same kinds of rough-and-tumble activities as their brothers, up until such time (typically between thirteen and fifteen) as society demanded that they become young ladies. Alluding to Carol Ryrie Brink's award-winning juvenile novel Caddie Woodlawn (1935), MacLeod writes:

Far from being unique, what I think of as the Caddie Woodlawn Syndrome seems to have been common in America during that period. In a surprising number of memoirs is an account of just such an experience of childhood freedom followed by just the same closing of the doors as the girl neared puberty. If autobiography can be accepted as any kind of sample of common practice, then it would seem that in a good many households the sharp differentiation between appropriate behavior and activity for prepubescent boys and girls was not as firmly applied as we often suppose. Many American women could and did look back to their childhood years as a period of physical and psychic freedom unmatched by anything in their later life. ("Caddie Woodlawn Syndrome" 99-100) ${ }^{41}$

MacLeod's research helps account for the popularity of Little Women, and especially of the beloved Jo. ${ }^{42}$ Not only did Jo's character exhibit many of the traits of MacLeod's tomboys-independence, courage, an adventurous spirit, and a love of the outdoors—but the problem with which Jo contends throughout Little Women was evidently a pervasive and enduring one for American girls: the problem of how to bridge the gap between the relative liberty of girlhood and the potentially stifling constraints of womanhood. ${ }^{43}$

This overarching concern in Alcott's girls' books was well accommodated to the momentum of the juvenile book market, which demanded of every popular children's novel a sequel. In writing Little Women, 
Alcott quickly established a narrative pattern that she repeatedly turned to in the eight volumes that ultimately formed the Little Women Series. According to this pattern, Alcott would first introduce as her heroine a young girl on the brink of adolescence. After presenting, as a series of episodes, the ins and outs, ups and downs, of girl-life, she would then reintroduce her heroine as a young woman in a continuation or sequel (contingent on the popularity of the initial part). Set several years later, these sequels reintroduced the heroine as a young woman. Thus Jo's declaration in the first chapter of Little Women, "I hate to think I've got to grow up, and be Miss March, and wear long gowns, and look prim as a China-aster!" (5), presents a conflict that naturally carries over to Little Women, Part Two (1869), ${ }^{44}$ set three years later, when Jo has reached the age of nineteen. ${ }^{45}$ Similarly, An Old-Fashioned Girl (1870) originally consisted of only seven chapters, which take place during Polly Milton's fifteenth year. ${ }^{46}$ As Alcott states in her preface, however, ". . . the demand for a sequel, in beseeching little letters that made refusal impossible, rendered it necessary to carry my heroine boldly forward some six or seven years into the future," a feat she accomplished in twelve additional chapters. In Little Men: Life at Plumfield with Jo's Boys (1871), in which Jo's character has matured and stabilized, the action shifts to a younger generation of boys and girls. Its sequel, Jo's Boys and How They Turned Out (1886), which begins ten years after the conclusion of Little Men, adheres to the pattern, following not only the progress of the boys-Dan, Nat, Demi, and the others-but also of the girls—most notably "Naughty Nan," who has grown into "Dr. Nan." By the time she introduced her readers to thirteen-and-a-half-year-old Rose Campbell in Eight Cousins or The Aunt-Hill (1875), the pattern was so entrenched that Alcott was able to announce in her preface her intention to follow it with a second volume, "which shall attempt to show the Rose in Bloom." ${ }^{, 47}$ According to its preface, Rose in Bloom (1876), in which Alcott reintroduced her heroine (along with her friend Phebe and her seven boy cousins) two years advanced in age, "was simply written in fulfillment of a promise; hoping to afford some amusement, and perhaps here and there a helpful hint, to other roses getting ready to bloom."

Of course, not all of Alcott's girl heroines can properly be termed tomboys; nevertheless, in each case, their stories serve to illustrate the wisdom of the following observation, put into the mouth of Uncle Alec in Rose in Bloom:

To me there is something almost pathetic in the sight of a young girl standing on the threshold of the world, so innocent and hopeful, so ignorant of all that lies before her, and usually so ill prepared to meet the ups and downs of life. We do our duty better by the boys; but the poor little women are seldom provided with any armor worth having; and, sooner or later, they are sure to need it, for every one must fight her own battle, and only the brave and strong can win. (8)

The fact that each of these narratives elides the period, ranging from two to six years in length, 
during which the girl evolves into a young woman underscores the difficulty and protracted nature of the transition between childhood and adulthood. ${ }^{48}$ Despite these absences of several years, Alcott's heroines do not return from the hiatus ready-made, like butterflies emerging from their chrysalises. Instead, Alcott continues to explore the process of becoming, rather than being, an adult. ${ }^{49}$ Her silence during the pivotal years of adolescence suggests that, for Alcott, the crucial task was not to chart every step of the journey or artificially compress a girl's "coming of age" into a single dramatic moment, but rather to reassure her readers as to what lay on the other side of the daunting divide between girlhood and womanhood, and to persuade them that marriage was only one of many alternatives. ${ }^{50}$

The practice of spinning off sequels and series was a marketing innovation that flourished in the late nineteenth and early twentieth centuries - an indication that authors and publishers were becoming quite adept at catering to the demands of the marketplace — and, as indicated earlier, William T. Adams and his publisher, Lee \& Shepard, were masters of the technique. According to Kilgour, "Oliver Optic, for better or for worse, was certainly the great initiator of this method of mass production of books for children" (Lee and Shepard 270), a strategy that became standard practice in the years following the Civil War. Kilgour explains:

It was the appearance of similar series on every publisher's lists that provoked the comment from The Independent, two years later: "The fashion of publishing books in sets, which has been growing for some time, seems now to be at its hight [sic]. Every other book is issued in some library or other; and since publishers follow, rather than create public taste, we infer that buyers prefer to purchase books of whose general nature they can tell something by the title of the series to which they belong." (Lee and Shepard 167-68) (1 $^{51}$

Of course, publishers do more than merely follow public taste, and to Lee \& Shepard belongs much of the responsibility for creating, or encouraging, the trend for authors to write and publishers to package juvenile books in series and sets.

If Thomas Niles had indeed persuaded Alcott to follow the example of Oliver Optic and write books directed specifically at a single-sex juvenile audience, it is likely that he also had Adams's success with series in mind when he urged the author of Little Women to follow up with subsequent volumes of the "March Family Chronicles." Alcott complained in a letter of February 1869, "I [d]ont like sequels, \& dont think No 2 will be as popular as No 1, but publishers are very perwerse \& wont let authors have thier [sic] way so my little women must grow up \& be married off in a very stupid style" [Letters 121-22]. ${ }^{52}$ ) But Niles, who "[1]ike most publishers . . . felt that books sold better in series, since a few outstanding titles would carry a mass of trivia" (Kilgour, Roberts Brothers 65), had already decided, within a month of the publication of Little Women, that the story should have a sequel. ${ }^{53}$ Moreover, he encouraged Alcott to keep 
the ending of Little Women open to allow for such a possibility (Shealy 63), ${ }^{54}$ and when Little Women or Meg, Jo, Beth and Amy Part Second was still in press, he was already urging Alcott to follow it up with a "new story by Miss Alcott" (Shealy 71). Alcott's next girls' book was An Old-Fashioned Girl, and no sooner was it published than Niles was once again persuading Alcott of the need to satisfy her audience by following up with Little Men (Shealy 81). Alcott wrote Jo's Boys, too, at the prompting of Niles, who felt that the book was "needed to keep up the enthusiasm \& renew the demand" for the earlier books (qtd. in Shealy 245). Even after she had written eight novels for the Little Women Series, Niles was still coaxing her to add more, informing her that even though "he did not 'like serials,' he would be 'sorry to deprive [her] of the really fabulous sum' which they offered" (Shealy 195). ${ }^{55}$

Alcott readily acknowledged her indebtedness to Niles in establishing her as a famous writer of books for girls, even referring to Little Women as a book that was "very hastily written to order" (Letters 118). Her debt to Oliver Optic and the Lee \& Shepard mode of mass production and marketing remained largely unacknowledged, however, by both Alcott and her publisher. In fact, Alcott evidently came to regard Adams and his myriad series books with disdain. In An Old-Fashioned Girl, she presents a caricature of contemporary boys' books, depicting Tom Shaw "absorbed in one of those delightful books in which boys are cast away on desert islands, where every known fruit, vegetable and flower is in its prime all the year round; or, lost in boundless forests, where the young heroes have thrilling adventures, kill impossible beasts, and, when the author's invention gives out, suddenly find their way home, laden with tiger skins, tame buffaloes and other pleasing trophies of their prowess" (77). More pointedly, in Eight Cousins, she attacks sensational stories as "optical delusions" and complains about the use of slang in popular boys' books, a rhetorical sally that provoked a cutting riposte from Adams. ${ }^{56}$ As the parallel and intertwining careers of Louisa May Alcott and Oliver Optic show, however, both authors succeeded in the rapidly expanding literary marketplace by staking out segments of the juvenile fiction market defined principally by gender and age ${ }^{57}$ Both authors effectively responded to the literary tastes and interests of these audiences, and both paid heed to the aspirations of their readers, as well as to the expectations society placed upon them. The books of both authors were created and shaped by the markets they addressed, and, in turn, shaped, defined, and fostered a sense of community among these respective groups of readers. ${ }^{58}$

In Woman's Fiction: A Guide to Novels By and About Women, 1820-1870, Nina Baym comments on the nearly simultaneous publication of the initial volumes of Martha Finlay's Elsie Dinsmore in 1867 and Little Women the following year, both books inaugurating series that would become spectacularly successful. According to Baym:

These two publishing events marked ... the decline of woman's fiction . . . because they represent the transformation of woman's fiction into girl's fiction. The story of feminine heroism now becomes a didactic instrument for little girls . . . (296)

Wadsworth 14 
Far from signaling the degradation or marginalizaton of women's fiction, however, the incidents Baym points to are actually part of a much larger progression encompassing both the rise to dominance of female readers in the nineteenth-century literary marketplace and the ascendancy of girls in the expanding market for juvenile books, in conjunction with the gradual supplanting of "True Woman" by "New Woman" as acceptable models of femininity. Rather than representing a diminution or reduction of woman's fiction, therefore, the publication of Little Women and its sequels heralded an exciting and important development in United States social history: girls had at last come into their own as a discrete, viable, cohesive component of the American literary enterprise.

\section{Acknowledgments}

I am grateful to the University of Minnesota Graduate School for funding the research and writing of this paper through a Doctoral Dissertation Fellowship. I wish also to thank Donald Ross, Jr., Edward M. Griffin, Michael Hancher, Emily B. Todd, and Karen Woods Weierman for commenting on drafts of the paper.

\section{Notes}

1. John Newbery experimented with gender-based marketing gimmicks by packaging A Little Pretty Pocket Book (1744) with a ball for boys and a pincushion for girls, but this strategy was designed to make a single book equally attractive to both male and female children. Samuel F. Pickering, Jr. traces the first "significant differentiation made between books for little girls and for little boys" to Mary Ann Kilner's The Adventures of a Pin Cushion (1783?) and Memoirs of a Peg-Top (1783) (qtd. in Segal, “As the Twig Is Bent"” 168).

2. Jacob Abbott's Rollo and Lucy books (dating from 1835 and 1841, respectively) are the first American juvenile series of note to be clearly differentiated by gender. The series I discuss in this article targeted a slightly older age group than Abbott's series. For a bibliographical overview of series books for girls, see Girls Series Books: A Checklist of Titles Published, 1840- 1991 (Minneapolis: U of Minnesota P, 1992). For discussions of gender-differentiation in the British market, see Kimberley Reynolds, Girls Only? Gender and Popular Children's Literature in Britain, 1880-1910 and J. S. Bratton, The Impact of Victorian Children's Fiction.

3. It is significant that Sheryl A. Englund refers to Little Women as a "genre-defining 'girl's book"” (201) and Cary Ryan pronounces it "a book that redefines what it means to be born a girl" (Alcott, Girlhood Diary 36). I argue that her books for girls are both "genre-defining" and audience-defining and that the two functions are, in fact, interdependent.

4. This was the kind of juvenile literature Alcott read, or listened to, in her own childhood. 
Her childhood diary records her reading, or being read, stories by Edgeworth and Fredrika Bremer. This reading is reflected in that of Marmee and the March girls in Little Women. (See Alcott, Girlhood Diary and Crisler.)

5. Alcott's first book, Flower Fables (dated 1855), was published by George W. Briggs \& Company for the Christmas trade in December 1854, with a first edition of 1,600. The book, dedicated to Ellen Emerson and sponsored by Sophia Hawthorne (Payne xi), was based on stories a sixteen-year-old Alcott had made up to amuse the nine-year-old daughter of Ralph Waldo Emerson (Shealy, Fairy Tales xxi-xxii). Of this book, Alcott wrote, “. . . I hope to pass in time from fairies and fables to men and realities" (Letters 11). All of Alcott's fantasy stories can be found in Louisa May Alcott's Fairy Tales and Fantasy Stories.

6. The Rose Family. A Fairy Tale was published by James Redpath in 1864, and Horace B. Fuller brought out Morning Glories, and Other Stories in 1868. As Shealy points out, Alcott returned to fantasy stories from time to time in her magazine fiction (republished in Aunt Jo's Scrap-Bag) and in Lulu's Library. See "Introduction” to Louisa May Alcott's Fairy Tales and Fantasy Stories.

7. "Robert Merry" was a pseudonym of Samuel Griswold Goodrich ("Peter Parley”), who launched Merry's Museum in 1841. Horace B. Fuller acquired the magazine in 1867 and hired Alcott to edit it at an annual salary of $\$ 500$.

8. Its title as well as its structure clearly influenced by Hawthorne, Will's Wonder Book, a collection of dialogues between two children and their grandmother about animals and insects, appeared in Merry's Museum from April to November 1868 and was published in book form by Horace B. Fuller in 1870. In her journal, Alcott also recorded writing “Jamie's Wonder Book” (Journals 131). Madeleine Stern speculates that this was an earlier title of Will's Wonder Book. See the introduction to Louisa May Alcott, Louisa's Wonder Book: An Unknown Alcott Juvenile (Central Michigan UP, 1975). Alcott wrote fantasy stories for Youth's Companion, St. Nicholas, and Harper's Young People as well.

9. For Whitman, a close friend of Alcott's, "the sweetest and most attractive side of her nature" was "her real love for boys, which sprang from the boy nature that was hers in so marked a degree" (5). According to Whitman, "she always said she ought to have been a boy, and that she could not be was one of the many crosses she had to bear" (6). Even toward the end of her life, after her success with girls' fiction had become nearly legendary, Alcott expressed distaste for the genre of girls' books, remarking in a letter to a reader, “'Little Women' was written when I was ill, \& to prove that I could not write books for girls. The publisher thought it flat, so did I, \& neither hoped much for or from it. We found out our mistake, \& since then, though I do not enjoy writing 'moral tales' for the young, I do it because it pays well" (Letters 232). Alcott's resistance to the genre shows up in feisty, unconventional characters like Jo March and Nan Harding. 
10. Of her childhood, Alcott wrote, "No boy could be my friend till I had beaten him in a race, and no girl if she refused to climb trees, leap fences, and be a tomboy" (Girlhood Diary 1). At the age of 13, she recorded in her journal, "I am old for my age, and don't care much for girl's [sic] things. People think I'm wild and queer" (Girlhood Diary 34).

11. The first part of Little Women was published in early October 1868, with a first printing of 2,000 copies. For details of sales, see Myerson and Shealy.

12. George Haven Putnam explained: "The firm of Roberts Bros. began in the later sixties a publishing business which, largely through the efforts of its literary manager, Mr. Niles, won prompt reputation for its recognition and effective management of good literature, English and American" (62).

13. In his history of Lee and Shepard, Raymond L. Kilgour speculates further about this connection between Adams and Alcott on the eve of Little Women, suggesting that Niles "must have mentioned the tremendous success of the Optic books as an inducement" for Alcott to attempt a book for girls (Lee and Shepard 73). Sarah Elbert concurs that "Niles wanted to tap the market for girls created by popular writers of boy's fiction like 'Oliver Optic'" (141) and further suggests that "Louisa's incentive to write Little Women had been the Oliver Optic series . .." (181). Despite these rather tantalizing hints of a channel of influence between Adams and Alcott, the connection has remained largely unexplored.

14. New York's Sunday Times declared that "“Oliver Optic"” is a nom de plume that is known and loved by almost every boy of intelligence in the land" (qtd. in Lee and Shepard catalog, rpt. Dzwonkoski), and Hurst \& Co., who republished "Oliver Optic Books for Boys" in the early twentieth century, stated that "[f]ew boys are alive to-day who have not read some of the writings of this famous author, whose books are scattered broadcast and eagerly sought for" (qtd. in Adams, Try Again, n. p.). In his memoir (1884), J. C. Derby reminisced of Oliver Optic's popularity:

Of the hundreds of thousands of copies published and scattered broadcast throughout the land, thousands found a ready market in Sunday school libraries of Western towns. So clamorous was the demand for these books, augmented by the fact that the scarcity of public libraries put them beyond the reach of many, that in some places the one or two Sunday schools which first placed the coveted treasures upon their shelves, soon found their churches far too small to hold their accessions of scholars from far and near; and not only did recruits pour in from the ranks of habitual non-attendants, but there was a general exodus from the Sunday schools of less enterprising denominations. (525)

15. Adams's first two books were for adult readers. These were Hatchie, the Guardian Slave; 
Or, The Heiress of Bellevue. A Tale of the Mississippi and the Southwest (1852) and In Doors and Out: Or, Views from the Chimney Corner (1854).

16. An article in the American Literary Gazette, 15 July 1871, declared, "It is, no doubt, safe to state this firm [Lee \& Shepard] publishes a larger number of juvenile books than any other house in the country" (qtd. in Kilgour, Lee \& Shepard 114). According to Putnam, "[t]he publication of books for young people constituted the chief interest during this decade of the firm of Lee \& Shepard .... 'Oliver Optic' and Martha Finley, the author of the Elsie books [published by Dodd, Mead], were writers whose volumes obtained the largest popularity with the children of this generation" (63).

17. In Lee and Shepard: Publishers for the People, Kilgour pejoratively refers to the firm's "many new series, cleverly devised for preying on the young" and declares that "their advertising was almost modern in its abundance, its ceaseless reiteration, its frequent cleverness and equally frequent blatancy" (137).

18. Sometimes the connections among these books were rather forced. Kilgour explains: "A novel selling device, perhaps original with L\&S and, in any case, more efficiently employed by them at an earlier date than by any other firm, was the grouping of titles only faintly related in high-sounding sets" (95). As examples, Kilgour cites "The Frontier Series" and "The Wonderland Series," each containing books by more than one author. The technique became quite common. Horace B. Fuller included Alcott's Morning-Glories, and Other Stories in his multiauthor "Morning Glory Series," and Will's Wonder Book was part of his "Dirigo Series."

19. Also called the Oliver Optic Series, and later retitled The Famous Boat Club Series: A Library for Young People, Oliver Optic's Library for Young People consisted of The Boat Club, Or the Bunkers of Rippleton (1854); All Aboard, Or Life on the Lake (1856); Now or Never, Or the Adventures of Bobby Bright (1856); Try Again, Or the Trials and Triumphs of Harry West (1857); Poor and Proud, Or the Fortunes of Katy Redburn (1858); and Little by Little, or the Cruise of the Flyaway (1860). The Riverdale Story Books consisted of twelve books aimed at readers aged from six to ten.

20. Of a slightly later period in Britain, Reynolds observes, “. . . as girls continued to demand more exciting books and to risk charges of unladylike behavior by secretly imbibing the contents of their brothers' libraries, it became evident that there was a need (and a market) for a literature which could satisfy their appetite for entertainment without the accompanying danger [boys' books were presumed to present]" (94).

21. Adams eventually produced a story about a girls' boat club, The Dorcas Club; or, Our Girls Afloat, but not until 1874, twenty years after The Boat Club. More importantly, as Adams points out in the preface to this novel, the real hero of the story is a boy, Prince Willingood. In fact, the girls of the Dorcas Club are little more than props, providing the hero with a convenient damsel in distress and 
the opportunity to flex his muscles and exercise his chivalry as "Professor" of rowing.

22. These include The Young Man's Guide by William Alcott (1833), Lydia Sigourney's The Boy's Reading-Book (1839), Horace Mann's A Few Thoughts for a Young Man (1850), and Henry Ward Beecher's Lectures to Young Men, on Various Important Subjects (1846).

23. A Hurst \& Co. advertisement from the early twentieth century stated that "Oliver Optic has the faculty of writing books full of dash and energy, such as healthy boys want and need, yet free from any objectionable dime-novel sensationalism" (in Try Again). (Italics added.). In 1879, T. W.

Higginson similarly emphasized boys' needs when he defended Adams's boys' books by declaring: “If . . . nothing takes hold of a neglected Irish boy, for instance, like Oliver Optic's stories, then I would give him Oliver Optic in copious draughts, and give it at public expense; he will be all the less likely to supply himself with The Police Gazette at his own cost" (qtd. in Kilgour, Lee \& Shepard 196).

24. According to Mary Noel, a similar phenomenon characterized American periodicals that carried fiction: "In the [eighteen] seventies most of the story papers were running a special serial for boys. This was in spite of the fact that many of the publishers were experimenting with other story papers designed especially for boys, or for girls, or for both. Boys were evidently considered apart from the rest of the family. The girls could read the adult stories and be quite happy. But boys wanted an occasional hero of their own age to act the part of a man" (217-18).

25. Lovett's sense of embarrassment was shared by a later generation of boys whose admiration of the movie version of Little Women led them to read Alcott's novel—but with the cover concealed by plain brown wrappers (Payne 56).

26. This detail provides an interesting, but little noticed, counterpoint to Jo's often remarked reading of The Wide, Wide World in her backyard apple tree.

27. As recently as 1986, Elizabeth Segal observed that "People who work with children can testify to the sad fact that reading a book about a girl is still cause for embarrassment for many young male readers" (“"As the Twig Is Bent”" 182). On the ironies of girls being permitted greater range in their reading than boys, despite greater social restrictions in other areas, see Reynolds, Girls Only? and Segal, “"As the Twig Is Bent." See Segal also for a provocative assessment of the "denigration of the female" implicit in these attitudes toward boys' and girls' reading and the disturbing ramifications for curriculum development.

28. Gillian Avery comments on this double standard in the development of entertaining, rather than purely didactic, literature for boys and girls, observing that adventure stories for boys "seem to have been far less closely scrutinized than fiction for girls — anything with geographical and zoological information in it being, apparently, deemed improving" (189).

29. The typical story by Oliver Optic, like those of his protégé Horatio Alger, corresponds in a 
general way to Alcott's description (cited earlier) of what she found "very brave \& beautiful" in the life of boys: "the sight of a boy when he first 'wakes up' \& seeing the worth of life takes it up with a stout heart \& resolves to carry it nobly to the end through all disappointments \& seeming defeats."

30. Mary Cadogan and Patricia Craig elaborate: “A separate, comprehensive body of girls' fiction did not come into being until the end of the last century: it was then a progressive sign, since it marked a recognition of the particular nature and interests of young girls. There is an intricate relation between a society and the kinds of expression it gives rise to, however, and girls' books quickly became a medium for the reinforcement of social prohibitions and expectations" (9).

31. As Lynne Vallone explains, "That adolescent or preadolescent boys and girls historically were not encouraged to share reading material emphasized the 'segregation' they would experience in later life through the separate-sphere economies of the domestic and commercial" (122).

32. As Englund notes, "The market was ripe for Alcott in 1868; the demand for secular juvenile books, especially novels for adolescent girls, and the extreme genre specialization of authors were new, even within the span of a few years in Alcott's own career" (202).

33. Not all reviewers agreed with the assertion of the Lady's Friend that the novel was "sure to influence them [girls] for good" (857). Whereas The Ladies' Repository of Boston declared, "Our Sabbath Schools will all want it" (“Our Book Table" 472), The Ladies' Repository of Cincinnati insisted that "it is not a Christian book. It is religion without spirituality, and salvation without Christ. It is not a good book for the Sunday School library" ("Contemporary Literature" 472). For a survey of contemporary reviews of Alcott's fiction, see Janet S. Zehr.

34. Alcott further developed this theme in Work: A Story of Experience (1873), a novel for adults.

35. In her preface to this novel, Alcott writes, "The 'Old-Fashioned Girl' is not intended as a perfect model, but as a possible improvement upon the Girl of the Period" (v).

36. Poor and Proud is arguably a girls' novel, although it was generally marketed as "a story for young people." The confusion over the audience for the book came to the forefront in 1886 when Lee \& Shepard reissued it as part of their American Boys' Series with the subtitle changed to "A Story for Girls."

37. Dolores Blythe Jones's An “Oliver Optic” Checklist: An Annotated Catalog-Index to the Series, Nonseries Stories, and Magazine Publications of William Taylor Adams includes no listing for "Katy Redmond." Presumably Elbert means "Redburn."

38. Gertie, the heroine of Maria Susanna Cummins's The Lamplighter (1854), a book for older readers, is a possible prototype for Katy Redburn.

39. In a retrospective article entitled "Books That Girls Have Loved" (1897), Erin Graham 
wrote of the March sisters: "We liked them all, but with one voice Jo was declared our favorite. Every girl whom I have known regards the boyish Jo with feelings of tenderness. Meg was more domestic, Amy more graceful, and Beth more gentle; but Jo, dear old blundering Jo, romped into our hearts at once" (430-31). Ryan describes Jo as "the first liberated girl in American literature" (xi).

40. In a journal entry of 26 August 1868, a month and a half prior to the publication of Little Women, Part One, Alcott recorded: "Proof of whole book came. It reads better than I expected. Not a bit sensational, but simple and true, for we really lived most of it; and if it succeeds that will be the reason of it. Mr. N. likes it better now, and says some girls who have read the manuscripts say it is 'splendid!"’ (Journals 166).

41. According to Christian McEwen, "It was not until 1876 that the word ['tomboy'] began to take on ... positive connotations. What Charlotte M. Yonge meant by tomboyism, she said, was 'a wholesome delight in rushing about at full speed, playing at active games, climbing trees, rowing boats, making dirt-pies, and the like"' (xii).

42. Jo was not the first tomboy heroine in American literature, although she was very close to it. According to Elizabeth Segal, the tomboy heroine "arrived on the scene with a splash in the decade following the Civil War" ("The Gypsey Breynton Series" 67) with Elizabeth Stuart Phelps's Gypsy Breynton (1866). Gypsy was soon followed by Jo March and Susan Coolidge's Katy Carr (the protagonist of What Katy Did [1872] and its sequels). As Segal notes, all three of these series were extremely popular and all inspired multiple sequels. Even some male authors picked up on the appeal of the tomboy heroine. In 1873, George M. Baker entered the scene with Running to Waste: The Story of a Tomboy, which Kilgour describes as "a story of country life, of an arrant tomboy who was reformed by her friends and turned into a bright and energetic young lady" (Lee and Shepard 156), and even Henry James touched on this theme in his first novel, Watch and Ward (1871). After Roger Lawrence installs his ward, Nora Lambert, at his country estate, his cousin Hubert remarks, “'I can't think of her as a girl.... she seems to me a boy. She climbs trees, she scales fences, she keeps rabbits, she straddles upon your old mare. I found her this morning wading in the pond. She is growing up a hoyden; you ought to give her more civilising influences than she enjoys hereabouts; you ought to engage a governess, or send her to school. It is well enough now; but, my poor fellow, what will you do when she is twenty?", (30).

43. Anna Quindlen calls Little Women "the first great American coming-of-age book for girls, the companion piece to Huck Finn's raft trips down the Mississippi." As Englund remarks, "Little Women has been and remains an important text, particularly for women readers: a text that has unquestionably informed nineteenth- and twentieth-century constructions of white, middle-class femininity" (216). 
44. In Britain, the second volume of Little Women was titled Good Wives. Starting in 1870, parts one and two of Little Women were published together as a two-volume set. Later, in 1880, they were combined into a single volume.

45. The last paragraph of Little Women, Part One informs readers that the appearance of a second part "depends upon the reception given to the first act of the domestic drama called 'Little Women"” (239).

46. An Old-Fashioned Girl initially appeared as a serial in Merry's Museum (July-December 1869).

47. Eight Cousins first appeared as a serial in Good Things: A Picturesque Magazine for the Young of All Ages in 1874.

48. The two remaining volumes of the Little Women Series, Under the Lilacs (1878) and Jack and Jill (1880), depart from the pattern by adhering to a continuous timeline. In Jack and Jill, however, Alcott obliges us with a proleptic "peep into futurity" (281), ten years hence, when Merry is living in Italy, the wife of a sculptor, Molly (like Maude in An Old-Fashioned Girl) is "a merry spinster" (281), and Jill marries Jack at the age of twenty-five. Both of these novels were serialized in St. Nicholas before being issued in book form.

49. Alcott's emphasis on becoming rather than being is reflected in Ryan's observation that "Louisa's writing has shown generations of readers who they are gently alongside what they could become, reassuring them that the distance in between is only a human step" (1), and in Barbara Sicherman's statement that reading Little Women "has been a rite of passage for generations of adolescent and preadolescent females of the comfortable classes" ("Reading Little Women" 247).

50. In her journal, Alcott recorded, "Girls write to ask me who the little women marry ... . I wont marry Jo to Laurie to please any one" (Journal 167). A few months later, she wrote to Alfred Whitman, "All my little girl-friends are madly in love with Laurie \& insist on a sequel . . . adding, "I wanted to disappoint the [little dears] young gossips who vowed that Laurie and Jo should marry" (Letters 120). In a letter to Elizabeth Powell dated 20 March 1869, Alcott elaborated, “'Jo' should have remained a literary spinster but so many enthusiastic young ladies wrote to me clamorously demanding that she should marry Laurie, or somebody, that I didn't dare to refuse \& out of perversity went \& made a funny match for her" (Letters 124-25). Given the unpopularity of Alcott's decision to have Jo marry Mr. Bhaer, it is significant that in the final chapter of An Old-Fashioned Girl, Alcott writes: “. . . intimidated by threats, denunciations, and complaints showered upon me in consequence of taking the liberty to end a certain story as I liked, I now yield to the amiable desire of giving satisfaction, and, at the risk of outraging all the unities, intend to pair off everybody I can lay my hands on" (314). Given her reluctance to marry Jo at all, it is also significant that she allows Maud, a relatively minor character, to 
remain "a busy, lively spinster all her days" (325).

51. Gillian Avery identifies this practice of "marketing books in named series" as "a particularly American phenomenon," one that presumably "saved bulk buyers the trouble of reading any more than the title" (190). Although neither Kilgour, the writer for The Independent, nor Avery takes into account the age of the typical buyer (adult or child?) and the relationship between buyer and reader (a parent buying for her or his child?), one can conclude that the practice of issuing books in named series might have been especially beneficial when the buyer was someone other than the primary reader, as is frequently the case with juvenile literature.

52. A month later, Alcott wrote to Elizabeth Powell, "A sequel will be out early in April, \& like all sequels will probably disappoint or disgust most readers, for publishers wont let authors finish up as they like but insist on having people married off in a wholesale manner which much afflicts me" (Letters 124-25). Alcott reiterated her dislike of sequels in 1876: 'Get an idea and start 'Rose in Bloom,' though I hate sequels" (Journals 201).

53. Alcott noted in her journal (30 October 1868) that "Mr. N. wants a second volume for spring" (Journals 167).

54. Niles persuaded Alcott to append a chapter to the first volume of Little Women "in which allusions might be made to something in the future" (qtd. in Shealy 71).

55. Niles even devised a spin-off series from the Little Women books: Aunt Jo's Scrap-Bag, six volumes (consisting mostly of short fiction) published from 1872 to 1882 . Earlier, he had suggested to Alcott the idea of publishing some of her letters from Europe in the guise of "Jo's Letters from Abroad to the March's [sic] at Home" or "Little Women and Little Men Letters" or "Letters to 'Jo' by 'Little Women' and 'Little Men"” (Sicherman, 254).

56. Adams aired his rebuttal and launched a counterattack in Oliver Optic's Magazine for 1875. Adams was not the first to turn the table on Alcott and charge that her novels employed slang. As Janet S. Zehr comments, "Several reviews [of Little Women] complained that children might learn bad grammar and diction from her book" (330).

57. Ironically, Alcott appears to have made an effort to move away from the female focus of Little Women by following it with Little Men, Eight Cousins, and Jo's Boys, all of which feature many more male characters than female. Later in her career, Alcott even projected a new story tentatively called "An Old-Fashioned Boy," admitting that she "had meant that for the title of a book, but another woman [Martha Finley] stole it" (Letters 248). The tale was to have for its protagonist a boy of the American Revolution. In addition, Alcott addressed boys as well as girls in her prefaces, "the little men and women, for whom it is an honor and pleasure to write" (An Old-Fashioned Girl vi). Nevertheless, the market was determined that she be a girls' author, and so she remains. For a recent critical reading 
from a male perspective, see Jan Susina, who laments "Alcott's refusal to create a subtly differentiated portrait of a male character" (170). For a discussion of Little Men as a "story of boys" (330) that "is not necessarily a boys' story" (325), see Beverly Lyon Clark.

58. As Barbara Sicherman comments, "Reading has long been recognized as a topic of absorbing interest to adolescents, especially adolescent girls. For girls books have represented an important arena for shared friendship as well as means of creating a world more satisfying than the one ordinarily inhabited, a world in which to formulate aspirations and try out different identities" ("Sense and Sensibility" 208). In support of Sicherman's generalization, a recent review of a current teen magazine asserts that "CICADA will grab teens who like to read. It will make them feel part of a community" (Hazel Rochman, Booklist; qtd. in publisher's promotional materials).

\section{Works Cited}

Adams, William Taylor. Little by Little; or, The Cruise of the Flyaway. Boston: Lee \& Shepard, 1860.

- Poor and Proud; or The Fortunes of Katy Redburn. Boston: Phillips, Sampson, 1856.

- Rich and Humble; or, The Mission of Bertha Grant. Boston: Lee \& Shepard, 1864.

—. Try Again, Or the Trials and Triumphs of Harry West. New York: Hurst \& Co., n. d.

Alcott, Louisa May. Eight Cousins or The Aunt-Hill. 1874. Boston: Little, Brown, 1996.

_. Jack and Jill. 1880. Boston: Little, Brown, 1999.

—. Jo's Boys and How They Turned Out. 1886. Boston: Little Brown, 1994.

- The Journals of Louisa May Alcott. Ed. Joel Myerson and Daniel Shealy. Boston: Little, Brown, 1989.

- Little Women or Meg, Jo, Beth, and Amy. 1868. Intro. Anna Quindlen. Boston: Little, Brown, 1994.

—. Louisa May Alcott's Fairy Tales and Fantasy Stories. Ed. Daniel Shealy. Knoxville: U of Tennessee P, 1992.

—. Louisa May Alcott: Her Girlhood Diary. Ed. Cary Ryan. Mahwah, NJ: BridgeWater Books, 1993.

—. An Old-Fashioned Girl. 1870. Boston: Little, Brown, 1997.

—. Rose in Bloom: A Sequel to Eight Cousins. 1876. Boston: Little, Brown, 1995.

- The Selected Letters of Louisa May Alcott. Ed. Joel Myerson, Daniel Shealy, and Madeleine B. Stern. Athens, GA: Univ. of Georgia P, 1995.

Avery, Gillian. Behold the Child: American Children and Their Books, 1621-1922. London: Bodley Head, 1994.

Baym, Nina. Women's Fiction: A Guide to Novels By and About Women, 1820-1870. Ithaca: Cornell UP, 1978. 
Bratton, J. S. The Impact of Victorian Children's Fiction. London: Croom Helm, 1981.

Cadogan, Mary, and Patricia Craig. You're a Brick, Angela! A New Look at Girls' Fiction from 1839 to 1975. London: Victor Gollancz, 1976.

Cheney, Ednah, ed. Louisa May Alcott: Her Life, Letters, and Journals. Boston: Roberts Brothers, 1889. Microfilm. New Haven, CT: Research Publications, Inc., 1975.

Clark, Beverly Lyon. "Domesticating the School Story, Regendering a Genre: Alcott's Little Men." New Literary History 26 (1995): 323-42.

“Contemporary Literature.” Rev. of Little Women. The Ladies' Repository (Cincinnati) (Dec. 1868): 471-73.

Crisler, Jesse S. “Alcott's Reading in Little Women: Shaping the Autobiographical Self." Resources for American Literary Study 20 (1994): 27-36.

Derby, J. C. Fifty Years Among Authors, Books and Publishers. New York: G. W. Carleton, 1884.

Dzwonkoski, Peter, ed. Dictionary of Literary Biography 49: American Literary Publishing Houses, 1638-1899. Detroit: Gale Research Company, 1986.

Elbert, Sarah. A Hunger for Home: Louisa May Alcott and Little Women. Philadelphia: Temple UP, 1984. Englund, Sheryl A. "Reading the Author in Little Women: A Biography of a Book." American Transcendental Quarterly (ATQ) 12 (1998): 199-219.

Evans, Ernestine. “Trends in Children's Books.” The New Republic 48 (1926): 338-39.

Gay, Carol. "William Taylor Adams.” Dictionary of Literary Biography 42: American Writers for Children Before 1900. Ed. Glenn E. Estes. Detroit: Gale Research—Bruccoli Clark, 1985.

Gleason, Gene. “What Ever Happened to Oliver Optic?” Wilson Library Bulletin 49 (May 1975): 647-50.

Graham, Erin. “Books That Girls Have Loved.” Lippincott's Magazine 60 (1897): 428-32.

Hunt, Linda C. A Woman's Portion: Ideology, Culture, and the British Female Novel Tradition. New York: Garland, 1988.

James, Henry. Watch and Ward. 1871. Phoenix Mill, Glouc., Eng.: Sutton Publishing, 1997.

Jones, Delores Blythe. An “Oliver Optic” Checklist: An Annotated Catalog-Index to the Series, Nonseries Stories, and Magazine Publications of William Taylor Adams. Westport, CT: Greenwood P, 1985.

Kilgour, Raymond L. Lee and Shepard: Publishers for the People. Hamden, CT: Shoe String Press, 1965. . Mssrs. Roberts Brothers, Publishers. Ann Arbor: U of Michigan P, 1952.

Lovett, Robert M. “A Boy’s Reading Fifty Years Ago.” New Republic 48 (1926): 336-38.

MacLeod, Anne Scott. American Childhood: Essays on Children's Literature of the Nineteenth and Twentieth Centuries. Athens, GA: U of Georgia P, 1994.

—. "The Caddie Woodlawn Syndrome: American Girlhood in the Nineteenth Century." In A Century of Childhood: 1820-1920. Mary Lynn Stevens Heininger, Karin Calvert, et al. Rochester, NY: The 
Margaret Woodbury Strong Museum, 1984.

McEwen, Christian. Jo's Girls: Tomboy Tales of High Adventure, True Grit, and Real Life. Boston: Beacon Press, 1997.

Myerson, Joel, and Daniel Shealy. “The Sales of Louisa May Alcott's Books.” Harvard Library Bulletin, $n s$ 1 (Spring 1990): 47-86.

“New Publications.” Rev. of Little Women. The Lady's Friend 5.2 (Dec. 1868): 857.

Noel, Mary. Villains Galore: The Heyday of the Popular Story Weekly. New York: Macmillan, 1954.

“Our Book Table.” Rev. of Little Women. The Ladies' Repository (Boston) (Dec. 1868): 468-72.

Payne, Alma J. Louisa May Alcott: A Reference Guide. Boston: G. K. Hall, 1980.

Putnam, George Haven. "Fifty Years of Books: A Sketch of Book Publishing in the United States in the Half-Century Succeeding 1860.” The Nation 101 (July 1915): 62-66.

Reynolds, Kimberley. Girls Only? Gender and Popular Children's Fiction in Britain: 1880-1910. New York and London: Harvester Wheatsheaf, 1990.

Salmon, Edward G. "What Girls Read." Nineteenth Century 20 (October 1886): 515-29.

Segal, Elizabeth. ““As the Twig Is Bent . . ': Gender and Childhood Reading.” In Gender and Reading: Essays on Readers, Texts, and Contexts, ed. Elizabeth A. Flynn and Patrocinio P. Schweickart. Baltimore: Johns Hopkins UP, 1986. 165-86.

—_. "The Gypsy Breynton Series: Setting the Pattern for American Tomboy Heroines." Children's Literature Association Quarterly 14 (1989): 67-71.

Shealy, Daniel. “The Author-Publisher Relationships of Louisa May Alcott.” Book Research Quarterly (Spring 1987): 63-74.

Sicherman, Barbara. "Reading Little Women: The Many Lives of a Text." In U. S. History as Women's History: New Feminist Essays, ed. Linda K. Kerber, Alice Kessler-Harris, and Kathryn Kish Sklar. Chapel Hill: U of North Carolina P, 1995. 245-66.

—. "Sense and Sensibility: A Case Study of Women's Reading in Late-Victorian America." In Reading in America: Literature and Social History, ed. Cathy N. Davidson. Baltimore: Johns Hopkins UP, 1989.

Stern, Madeleine. Louisa May Alcott: A Biography. New York: Random House, 1996.

Sumner, William G. “What Our Boys Are Reading.” Scribner's Monthly 15 (1878): 681-85.

Susina, Jan. "Men and Little Women: Notes of a Resisting (Male) Reader." In Little Women and the Feminist Imagination, ed. Janice M. Alberghene and Beverly Lyon Clark. New York: Garland, 1999. 161-72.

“T. Niles-In Memoriam.” Publishers Weekly 45.23 (June 9, 1894): 859-60.

Vallone, Lynne. Disciplines of Virtue: Girls' Culture in the Eighteenth and Nineteenth Centuries. New 
Haven: Yale UP, 1995.

Whitman, Alfred. “A Foreword. Miss Alcott's Letters to her 'Laurie.”" The Ladies' Home Journal 18 (Sept. 1901): 5-6.

Yonge, Charlotte. What Books to Give and What to Lend. London: National Society's Depository, 1887.

Zehr, Janet S. “The Response of Nineteenth-Century Audiences to Louisa May Alcott's Fiction.” ATQ (The American Transcendental Quarterly) N. S. 1 (198 7): 323-42. 